Vol. 2 | No. 2 | 2021 | Hal. 96-100

\title{
PEMANFAATAN RUMPUT ODOT SEBAGAI PAKAN ALTERNATIF TERNAK RUMINANSIA DENGAN HIGH NUTRITION RECOMMENDED FEED
}

\author{
Nisa'us Sholikah*, Wildan Auliya, Desita Ismayasari, Andika Septian Bachrul, Arrum \\ Novita Sari \\ Fakultas Peternakan, Universitas Islam Malang
}

*korespondensi email: nisaus.sholikah@unisma.ac.id

\begin{abstract}
ABSTRAK
Pakan ruminansia merupakan semua bahan pakan yang dapat dikonsumsi ternak, tidak menimbulkan suatu penyakit, dapat dicerna, dan mengandung zat nutrien yang dibutuhkan oleh ternak untuk keperluan hidup, reproduksi maupun proses perkembangan. Pakan dengan kualitas yang baik, memberikan efek terhadap ternak yaitu dapat meningkatkan produktivitas ternak. Rumput odot merupakan salah satu varian dari rumput gajah yang menjadi pakan favorit ternak ruminansia karena teksturnya yang lembut. Selain itu, kandungan nutrisinya juga mampu memenuhi kebutuhan ternak seperti sapi, kambing atau domba. Cara penanaman rumput odot sangat mudah dan sederhana. Metode yang kelompok kami gunakan yaitu dengan penyuluhan dan diskusi secara langsung mengenai bagaimana cara penanaman, perawatan, pemanenan dan pengolahan rumput odot. Rumput odot (Pennisetum purpureum cv.Mott) merupakan salah satu jenis rumput yang unggul dan memiliki produktivitas serta kandungan nutrisi yang cukup tinggi. Rumput odot memiliki ukuran yang lebih kecil daripada jenis rumput gajah yang lainnya. Rumput odot dapat tumbuh di berbagai jenis tanah serta sangat responsif terhadap pemupukan. Produksi yang berlimpah dan kandungan nutrisi yang cukup tinggi di banding jenis rumput gajah yang lainnya membuat rumput odot berpotensi untuk dijadikan pakan ternak dalam berbagai bentuk, seperti silase.
\end{abstract}

Kata Kunci: rumput odot; pakan; penyuluhan; nutrisi; peternak

\section{PENDAHULUAN}

Pakan Ruminansia merupakan semua bahan pakan yang dapat dikonsumsi ternak, tidak menimbulkan suatu penyakit, dapat dicerna, dan mengandung zat nutrien yang dibutuhkan oleh ternak untuk keperluan hidup, reproduksi maupun proses perkembangan (Haq et al., 2018; Haryanto, 2012). Pakan dengan kualitas yang baik, memberikan efek terhadap ternak yaitu dapat meningkatkan produktivitas ternak. Pakan yang diberikan pada ternak ruminansia umumnya berupa hijauan dan pakan penguat atau konsentrat (Nuraini et al., 2014; Sandi et al., 2019; Sari et al., 2016; Widarko \& Humaidah, 2018).

Pakan merupakan salah satu faktor terpenting dalam usaha pemeliharaan ternak, keberhasilan maupun kegagalan usaha ternak banyak ditentukan oleh pakan yang diberikan (Putri et al., 2020; Sunaryo \& Wadjdi, 2018). Produktivitas ternak 70\% dipengaruhi faktor lingkungan dan 30\% dipengaruhi faktor genetik (Ali et al., 2018). Faktor lingkungan pakan memiliki pengaruh paling besar sekitar 60\% - 70\%. Hal ini menunjukkan bahwa walaupun potensi genetik ternak tinggi, namun apabila pemberian pakan tidak memenuhi persyaratan potensi genetik yang dimiliki, maka produksi yang tinggi tidak akan tercapai. Pakan juga 
merupakan komponen produksi dengan biaya yang terbesar. Biaya pakan dapat mencapai 60 - 80\% dari biaya produksi. Perubahan fungsi lahan dan iklim membatasi ketersediaan hijauan pakan yang merupakan makanan pokok ternak ruminansia. Optimasi pemanfaatan limbah pertanian dan agroindustri dapat memperbaiki ketersediaan pakan. Pada umumnya kualitas limbah sebagai pakan sangat rendah sehingga perlu adanya upaya perbaikan pengelolaannya untuk menjadi pakan ternak yang dapat meningkatkan produktivitas ternak (Agustono et al., 2017; Gaina et al., 2019).

Penanaman rumput odot yang dibudidayakan banyak dilakukan peternak untuk memenuhi kebutuhan pakan ternak ruminansia. Rumput ini merupakan salah satu varian dari rumput gajah yang memang menjadi pakan favorit karena teksturnya yang lembut. Selain itu, kandungan nutrisinya juga mampu memenuhi kebutuhan ternak seperti sapi, kambing atau domba. Cara penanaman rumput od ot sangat mudah dan sederhana. Bibit odot bisa didapatkan dari perbanyakan vegetasi dengan metode setek. Rumput ini dikenal mudah ditanam dan memiliki produktivitas yang tinggi. Tak hanya kambing dan domba, rumput odot dapat digunakan sebagai pakan ternak lainnya seperti sapi, kelinci, dan kerbau.

Permasalahan yang terjadi di lapangan, tepatnya di Dusun Gondang, Kecamatan Bumiaji, Kota Batu yakni pemanfaatan rumput odot sebagai alternatif pakan ternak ruminansia masih minim, sehingga kami melakukan penyuluhan kepada peternak mengenai kandungan nutrisi yang tinggi dalam rumput odot ini, sehingga dapat bermanfaat sebagai pakan ternak utamanya meningkatkan produktivitas ternak.

\section{METODE}

Metode yang kelompok kami gunakan yaitu dengan penyuluhan dan diskusi secara langsung mengenai bagaimana cara penanaman, perawatan, pemanenan dan pengolahan rumput odot sehingga dapat bermanfaat sebagai pakan ternak ruminansia. Pelaksanaan penyuluhan ini kami lakukan di salah satu kandang peternak rakyat di Dusun Gondang pada hari Senin, 1 Maret 2021 pukul 08.00-10.00 WIB. Sasaran penyuluhan kami yaitu masyarakat desa, terutama peternak rakyat yang mana masih minim pengetahuanya mengenai kandungan nutrisi dari rumput odot. Setelah melakukan penyuluhan kami juga melakukan praktek secara langsung agar ilmu yang didapatkan dapat diterapkan masyarakat.

\section{HASIL DAN PEMBAHASAN}

Penyuluhan mengenai kandungan nutrisi dalam rumput odot yang kami lakukan dilaksanakan pada satu tempat, yakni di Dusun Gondang, Desa Tulungrejo, Kecamatan Bumiaji, Kota Batu. Kegiatan ini bekerja sama dengan pemuda Karang Taruna Dusun Gondang yang mana mereka membantu dalam sosialisasi kepada masyarakat sehingga mereka tergugah untuk datang dalam acara penyuluhan. Kegiatan ini dimulai dengan pembukaan, sambutan, acara inti (penyuluhan), diskusi dan penutupan. Pada sesi penyuluhan, kami menggunakan alat bantu berupa Power Point, Video dan alat peraga.

Penyuluhan yang kami lakukan yaitu mengenai pemanfaatan rumput odot sebagai pakan alternatif ternak ruminansia dengan high nutrition recommended feed yang mana kegiatan tersebut merupakan bagian dari program kerja KSM-Tematik Unisma Kelompok 62 berbasis Keilmuan dan Domisili.

Pada kegiatan tersebut kami melakukan penyuluhan mengenai kandungan dan manfaat dari rumput odot yang memiliki nutrisi tinggi sehingga sangat cocok jika dijadikan sebagai pakan alternatif ternak. Selain penyuluhan, kami juga membagikan dan membantu menanam bibit rumput odot kepada masyarakat setempat untuk ditanam di ladang/kebun masing-masing. 
Rumput odot (Pennisetum purpureum cv.Mott) merupakan salah satu jenis rumput yang unggul dan memiliki produktivitas serta kandungan nutrisi yang cukup tinggi. Rumput odot memiliki ukuran yang lebih kecil daripada jenis rumput gajah yang lainnya. Rumput odot dapat tumbuh di berbagai jenis tanah serta sangat responsif terhadap pemupukan (Wiwik, 2018).

Rumput odot merupakan rumput yang tumbuh berumpun dan terus-menerus menghasilkan anakan jika dilakukan pemangkasan secara teratur. Produksi yang berlimpah dan kandungan nutrisi yang cukup tinggi di banding jenis rumput gajah yang lainnya membuat rumput odot berpotensi untuk dijadikan pakan ternak dalam berbagai bentuk, seperti silase.

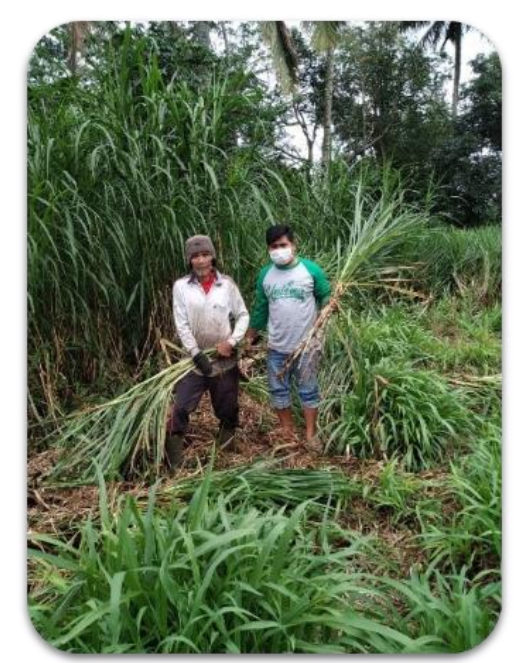

Gambar 1. Praktek secara langsung dengan peternak Dusun Gondang

Setelah sesi penyuluhan selesai, masyarakat mendiskusikan mengenai masalah yang terjadi di lapangan, tak lupa kami juga menjawab mengenai persoalan tersebut sesuai dengan pengalaman dan ilmu yang kita dapat di bangku perkuliahan. Setelah acara penyuluhan selesai, kami bertolak ke landang salah satu warga untuk melakukan penanaman bibit rumput odot dan melakukan edukasi dalam hal penanaman rumput odot hingga pengolahannya secara sederhana.

Salah satu contoh olahan dari rumput odot ini yaitu silase. Langkah awal dalam pembuatan pakan silase yaitu melakukan pencacahan rumput dengan ukuran yang kecil. Kemudian menyiapkan ember yang telah dituangkan air sebanyak 1,5 liter dan ditambahkan larutan tetes tebu sebanyak $300 \mathrm{ml}$, lalu ditambahkan garam $1 \mathrm{sdm}$ dan 5 tutup botol EM4. Potongan rumput yang telah tersedia kemudian ditaburi bekatul secukupnya sesuai dengan banyaknya rumput odot yang digunakan, lalu dituangkan larutan yang telah dibuat sebelumnya secara merata diatas potongan rumput dan bekatul. Langkah selanjutnya yakni mengaduk semua bahan hingga merata, kemudian semua bahan dimasukkan ke dalam ember atau drum dengan dilakukan penekanan agar tidak terdapat udara didalam drum yang dapat mengagalkan proses fermentasi saat penyimpanan. Drum ditutup plastik dan diikat dengan karet ban kemudian dilakukan penyimpanan selama 14 hari. Hasil produk silase dapat diberikan pada ternak apabila memiliki ciri - ciri silase yang baik seperti berbau manis wangi, tidak lembek, warna tidak hitam pekat.

Pelatihan pembuatan silase ini diharapkan agar peternak mampu membuat silase untuk pakan cadangan dengan mudah dan dengan harga yang terjangkau, terlebih ketika musim kemarau dalam kondisi sulit karena pandemi Covid-19 seperti sekarang. Di Dusun 
Gondang ini masyarakat sangat antusias dalam mengikuti program yang kami lakukan, karena bagi mereka ilmu seperti ini jarang didapatkan peternak di desa.

\section{KESIMPULAN}

Pemberdayaan masyarakat mengenai pemanfaatan rumput odot sebagai pakan alternatif ternak ruminansia dengan high nutrition recommended feed kami lakukan di Dusun Gondang, Desa Tulungrejo, Kecamatan Bumiaji, Kota Batu dengan sasaran peternak rakyat khususnya ternak ruminansia. Penyuluhan yang kami lakukan berupa edukasi kepada masyarakat terutama peternak mengenai kandungan dari rumput odot yang kaya akan nutrisi. Selain penyuluhan kami juga melakukan praktek mulai dari penanaman, perawatan, pemanenan dan pengolahan rumput odot sehingga dapat bermanfaat sebagai pakan ternak ruminansia.

\section{UCAPAN TERIMA KASIH}

Terimakasih kami sampaikan kepada pihak LPPM Universitas Islam Malang (UNISMA) yang telah memfasilitasi kami dalam belajar mengabdi pada masyarakat secara langsung. Terimakasih juga kami sampaikan kepada beberapa pihak seperti pemerintah Desa Tulungrejo dan masyarakat Dusun Gondang yang kami jadikan sebagai tempat pengabdian KSM-Tematik kelompok 62. Tak lupa kami sampaikan terimakasih kepada dosen pembimbing yang dengan sabar membimbing kami dari awal hingga akhir pelaksanaan program KSM-Tematik kelompok 62 ini.

\section{DAFTAR RUJUKAN}

Agustono, B., Lamid, M., Ma, A., \& Purnama, M. T. E. (2017). Identifikasi Limbah Pertanian dan Perkebunan Sebagai Bahan Pakan Inkonvensional di Banyuwangi. Jurnal Medik Veteriner, 1(1), 12-22. https://doi.org/10.20473/jmv.vol1.iss1.2017.12-22

Ali, U., Sumartono, \& Humaidah, N. (2018). IbM Kelompok Bisnis Peternakan Kambing Dan Domba Sebagai Hewan Qurban Dan Aqiqohan Di Karangbesuki, Sukun, Malang. Jurnal Inovasi Hasil Pengabdian Masyarakat (JIPEMAS), 1(2), 105-118. https://doi.org/10.33474/jipemas.v1i2.1515

Gaina, C. D., Datta, F. U., Sanam, M. U. ., Laut, M. M., Simarmata, Y. T. R. M. R., \& Amalo, F. A. (2019). Pemanfaatan Teknologi Pengolahan Pakan untuk Mengatasi Masalah Pakan Ternak Sapi di Desa Camplong II. Jurnal Pengabdian Masyarakat Peternakan, 4(1), 7184. https://doi.org/10.35726/jpmp.v4i1.274

Haq, M., Fitra, S., Madusari, S., \& Yama, D. . (2018). Potensi kandungan nutrisi pakan berbasis limbah pelepah kelapa sawit dengan teknik fermentasi. Prosiding Seminar Nasional Sains Dan Teknologi, 2015, 1-8. https://jurnal.umj.ac.id/index.php/semnastek/article/view/3537

Haryanto, B. (2012). Perkembangan penelitian nutrisi ruminansia. Jurnal Wartazoa, 22(4), 169-177.

Nuraini, Budisatria, I. G. S., \& Agus, A. (2014). Pengaruh Tingkat Penggunaan Pakan Penguat Terhadap Performa Induk Kambing Bligon di Peternak Rakyat. Buletin Peternakan, 38(1), 34-41. https://doi.org/10.21059/buletinpeternak.v38i1.4614

Putri, T. D., Siregar, T. N., Thasmi, C. N., Melia, J., \& Adam, M. (2020). Faktor-Faktor yang Memengaruhi Keberhasilan Inseminasi Buatan pada Sapi di Kabupaten Asahan, Sumatera Utara. Jurnal Ilmiah Peternakan Terpadu, 8(3), 111-119. https://doi.org/10.23960/jipt.v8i3.p111-119

Sandi, S., Desiarni, M., \& Asmak. (2019). Manajemen Pakan Ternak Sapi Potong di Peternakan Rakyat di Desa Sejaro Sakti Kecamatan Indralaya Kabupaten Ogan Ilir. Jurnal 
Peternakan Sriwijaya, 7(1), 21-29. https://doi.org/10.33230/jps.7.1.2018.7080

Sari, A., Liman, \& Muhtarudin. (2016). Potensi Daya Dukung Limbah Tanaman Palawija Sebagai Pakan Ternak Ruminansia Di Kabupaten Pringsewu. Jurnal Ilmiah Peternakan Terpadu, 4(2), 100-107. https://doi.org/10.23960/jipt.v4i2.1260

Sunaryo, \& Wadjdi, F. (2018). Kelompok Ternak Itik Pedaging Hasil Hibridisasi Kingbell Desa Gadingkulon, Dau, Kabupaten Malang. Jurnal Inovasi Hasil Pengabdian Masyarakat (JIPEMAS), 1(2), 152-164. https://doi.org/10.33474/jipemas.v1i2.1523

Widarko, A., \& Humaidah, N. (2018). IbM Peternakan Kambing Yang Memanfaatkan Limbah Pembuatan Tempe Junrejo Batu. Jurnal Inovasi Hasil Pengabdian Masyarakat (JIPEMAS), 1(1), 71-85. https://doi.org/10.33474/jipemas.v1i1.1480 